\title{
Analisis Kebijakan Peraturan Daerah Yang Mengandung Materi Muatan Ajaran Islam Di Kota Palembang
}

\author{
Kiki Mikail, Yazwardi
}

\begin{abstract}
This research is analytical descriptive research. This study places policy analysis and as the main and free variable that will influence the process of establishing a Regional Regulation as a dependent variable. In article 5 of the Republic of Indonesia Constitution states that the regional government has the right to determine regional regulations or other regulations in order to carry out regional autonomy.The local government of Palembang has issued three local government regulations that have Islamic sharia laws, namely regional regulation number 2 of 2004 concerning the eradication of prostitution, regional regulation number 11 of 2006 concerning the prohibition of circulation and sale of alcoholic products and local regulations on zakat. in order to be right on target and more effective, some variables need to be considered by Palembang stakeholders so that the Regional Regulations that are stipulated are not just legality, but more than that it must be a general rule that all local regulations are made in order for the common good Palembang community.
\end{abstract}

\section{Keywords : Political Analys, local goverment regulations, local autonomy, the politics of sharia law}

\section{Pendahuluan}

Selain urusan pemerintah yang sepenuhnya tetap menjadi kewenangan pusat, terdapat bagian urusan pemerintah yang bersifat concurrent, artinya urusan pemerintahan yang penanganannya dalam bidang atau bagian tertentu dapat dilaksankan bersama-sama antara pemerintah pusat dengan pemerintah daerah. Hal tersebut menunjukkan bahwa ada bagian urusan yang menjadi kewenangan pemerintah pusat, ada bagian urusan yang diserahkan kepada pemerintah propinsi dan ada juga urusan atau kewenangan yang diserahkan kepada pemerintah kabupaten/kota.

Sebagai negara yang menganut paham demokrasi, maka proses legislasi peraturan perundang-undangan seharusnya mencerminkan nilai-nilai demokrasi. Indonesia sebagai negara hukum, ${ }^{1}$ juga menerapkan sistem demokrasi yang

${ }^{1}$ Secara historis, konsep negara hukum muncul dalam berbagai model, seperti negara hukum menurut Al Qur'an dan Sunnah atau nomokrasi Islam, negara hukum menurut konsep Eropa Kontinental yang dinamakan rechsstaat, negara hukum menurut konsep Anglo Saxon yang dikenal sebagai rule of law, konsep socialist legality, dan konsep negara hukum Pancasila. Konsep-konsep negara hukum ini memiliki dinamika sejarahnya masing-masing. Pada masa Yunani kuno pemikiran tentang negara hukum dikembangkan oleh para filusuf besar Yunani 
berasaskan Pancasila sebagai pedoman kehidupan berbangsa dan bernegara. Artinya, produk perundang-undangan harus bersumber dan dipandu oleh nilainilai Pancasila. Produk peraturan perundangan dalam bentuk peraturan daerah merupakan implementasi tugas pembantuan pemerintah pusat kepada pemerintah daerah sebagai wujud otonomi daerah (desentralisasi dan dekosentrasi) dan demokratisasi pemerintahan untuk menampung kondisi khusus daerah dan atau sebagai penjabaran lebih lanjut peraturan perundang-undangan yang lebih tinggi. Dengan demikian, perda sebagai bentuk keniscayaan demokratisasi seharusnya juga dilahirkan dari proses legislasi yang demokratis sesuai dengan politik hukum dan perundang-undangan.

\section{Metodologi Penelitian}

Penelitian yang menggunakan pendekatan kajian analisa kebijakan ini mendeskripsikan Perda yang mengandung muatan materi ajaran Islam sebagai produk hukum yang menimbulkan "masalah" secara akademis. Oleh karena itu, untuk memudahkan peneliti dalam pengumpulan data, maka dilakukan identifikasi masalah dalam penelitian ini yang merupakan pokok-pokok dalam studi politik hukum sebagai berikut:

Permasalahan pertama diidentikasi dengan pertanyaan:

1. Bagaimana interaksi politik dalam pembentukan peraturan daerah yang mengandung materi muatan ajaran Islam di Kota Palembang Propinsi Sumatera Selatan?

2. Apakah Raperda yang mengandung materi muatan ajaran Islam merupakan inisiatif legislatif atau prakarsa eksekutif ?

3. Apakah Raperda yang mengandung materi muatan ajaran Islam melibatkan tokoh-tokoh agama yang berkompeten ?

4. Apakah Raperda yang mengandung materi muatan ajaran Islam memiliki naskah akademik?

5. Apakah fungsi Perda yang mengandung materi muatan materi ajaran Islam bagi pemerintahan dan masyarakat?

Permasalahan kedua diidentifikasi dengan pertanyaan:

1. Bagaimana perubahan kehidupan masyarakat sehingga memerlukan peraturan daerah yang mengatur pengamalan ajaran Islam ?

2. Apakah substansi Peraturan Daerah yang mengandung muatan materi ajaran Islam sesuai dengan norma yang berlaku di masyarakat.?

Kuno, seperti Plato (429-347 s.M) dan Aristoteles (384-322 s.M). Secara embrionik, gagasan negara hukum telah dikemukakan oleh Plato dan Aristoteles, ketika ia mengintroduksi konsep Nomoi, sebagai karya tulis ketiga yang dibuat di usia tuanya. Sementara itu, dalam dua tulisan pertama, Politeia dan Politicos, belum muncul istilah negara hukum (Azhary, M. Tahir, 2007, NegaraHukum Suatu Segi Tentang Prinip-prinsip dilihat dari segi hukum Islam, Implementasinya pada Negara Madinah dan Masa Kini. Jakarta: Bulan Bintang. H. 73-74). Sebagai Negara hukum, Indonesia juga menganut sistem hukum campuran (mixed law) yaitu di samping berlakunya hukum perundang-undangan juga berlaku hukum adat, dan hukum Islam. Lihat Achmad Ali. 2009. Menguak Teori Hukum (Legal Theory) dan Teori Peradilan (Judicialprudence) Termasuk Interpretasi Undang-undang (Legisprudence). Jakarta. Kencana Prenada Media Group. H. 203204. 
3. Apakah substansi Peraturan Daerah yang mengandung muatan materi ajaran Islam sesuai dengan peraturan perundang-undangan yang berlaku atau sistem hukum yang berlaku?

4. Apakah substansi peraturan daerah yang mengandung muatan materi ajaran Islam tidak diskrimatif ?

5. Apakah substansi Peraturan Daerah yang mengandung muatan materi ajaran Islam tidak mengancam NKRI, karena hanya berlaku pada daerah tertentu?

Sedangkan permasalahan ketiga diidentifikasi dengan pertanyaan:

1. Bagaimana konsep ideal Ius Constituendum pada peraturan daerah yang mengatur pengamalan ajaran Islam ?

2. Bagaimana proses perubahan ius constitutum menjadi iusconstituendum tentang peraturan daerah yang mengatur pengamalan ajaran Islam ?

3. Dalam bidang apa produk proses perubahan iusconstitutum menjadi iusconstituendum peraturan daerah yang mengatur pengamalan ajaran agama?

\section{Kajian Pustaka (Literature Review)}

Penelitian tentang produk hukum peraturan daerah dan atau proses legislasi suatu produk perundang-undangan yang bersifat lokalitas kedaerahan sejauh yang diketahui peneliti sudah beberapa kali dilakukan. Akan tetapi yang spesifik berbicara tentang proses legislasi perda yang bernuansa syariah dalam perspektif analisis kebijakan dengan mengambil wilayah hukum Kota Palembang Provinsi Sumatera Selatan sejauh pengetahuan peneliti hingga kini belum ada. Kajian-kajian yang dituangkan dalam bentuk Penelitian yang memiliki keterkaitan epistemologis, ontologis, dan aksiologis namun berbeda dengan penelitian ini di antaranya ialah:

Anis Ibrahim, 2008, Legislasi Dalam perspektif Demokrasi: Analisis Interaksi politik dan Hukum Dalam proses Pembentukan Peraturan Daerah di Jawa Timur. Penelitian Program Doktor Ilmu Hukum Universitas Diponegoro. Penelitian yang ditemukan penulis masih dalam bentuk aslinya ini menganalisis berbagai produk legislasi dalam bentuk perda di Jawa Timur dari perspektif demokrasi. Menurutnya, banyak produk perda yang cacat karena tidak aspiratif, tidak demokratis, dan tidak sesuai dengan asas-asas peraturan perundangundangan yang baik. Legislasi perda yang bernuansa syariah disinggung hanya salah satu jenis perda yang ada di Provinsi Jawa Timur.

Ali Imron, 2008, Kontribusi Hukum Islam Terhadap Pembangunan Hukum Nasional (Studi Tentang Konsepsi Taklif dan Mas`uliyyat Dalam Legislasi Hukum). Penelitian Program Doktor Ilmu Hukum Universitas Diponegoro ini mengakaji secara spesifik mendalam tentang eksistensi dan kontribusi hukum Islam dalam pembangunan hukum nasional. Implementasi konsepsi taklif dan mas`uliyyat dalam legislasi hukum nasional dengan cara mengintegrasikan asasasas hukum dan mengintegrasikan istinbathahkam ke dalam hukum nasional.

A. Muntoha. 2009. Otonomi Daerah dan Perkembangan "PeraturanPeraturan Daerah Bernuansa Syariah" Penelitian Penelitian yang di pertahankan di Fakultas Hukum Program Pascasarjana Universitas Indonesia. Penelitian ini 
berkesimpulan bahwa kedudukan Perda yang bermuatan materi ajaran agama (Islam) dalam ketatanegaraan di Indonesia dijamin secara konstitusi yang secara eksplisit disebutkan pada Pasal 29 UUD NRI 1945. Perda yang bermuatan materi ajaran Islam yang muncul di pelbagai daerah di Indonesia merupakan refleksi sebagian warganegara yang menuntut jaminan konstitusional mereka dalam mengamalkan ajaran agama mereka.

Febrian dkk. 2009. Pembangunan Hukum Dan Konflik Undang-Undang Bidang Sektoral. Penelitian yang dilakukan atas kerjasama Pusat Studi Kebijakan Hubungan Pusat dan Daerah Fakultas Hukum Universitas Sriwijaya dengan Dewan Perwakilan Daerah Republik Indonesia memfokuskan kajian pada konflik undang-undang yang mencakup konflik substansial dari sejumlah UU sektoral. Misalnya, konflik aturan hukum di bidang pertanahan, lingkungan hidup, pengelolaan kesehatan, kehutanan, dan lain-lain. Fokus kajiannya menelaah UU sektoral dan turunannya seperti Peraturan Pemerintah, Keputusan Presiden, Peraturan Menteri, Keputusan Menteri, dan termasuk di dalamnya Peraturan Daerah.

Penelitian yang direncanakan ini lebih spesifik berbicara mengenai produk-produk perda yang bersubstansi ajaran agama (syariah) dari aspek legislasi dan materi hukumnya. Demikian juga lebih spesifik ketika menjadikan Undang-Undang tentang Pemerintahan Daerah (No. 22 Tahun 1999; No.32 Tahun 2004; Perppu No.03 Tahun 2005; Undang-Undang No.12 Tahun 2008; dan Undang-Undang No. 23 Tahun 2014) dengan Undang-Undang tentang Peraturan Pembentukan Undang-Undang (No. 10 Tahun 2004; dan No.12 Tahun 2011). Dan Undang-Undang Nomor 7 Tahun 2014 tentang MPR, DPR, DPD, dan DPRD.

Sedangkan dari segi wilayah penelitian berbeda dengan penelitian sejenis yaitu wilayah Sumatera Selatan. Pengambilan lokasi penelitian Sumatera Selatan karena wilayah ini pernah menjadi kesultanan Islam yang dikenal dengan Kesultanan Palembang Darussalam. ${ }^{2}$ Salah satu pemikir hukum pada masa kesultanan ini adalah Ratu Sinuhun ${ }^{3}$ yang diakui sebagai penulis kitab UndangUndang Simbur Cahaya.

\footnotetext{
${ }^{2}$ Menurut Catatan Hamka, Islam telah masuk ke Palembang dari Demak pada tahun 1440 M ketika ibu Raden Patah dikirim ke sana dari Majapahit. Adipati Majapahit (yang ditugaskan di Palembang) pada waktu itu adalah Ario Damar yang kemudian berganti nama Ario Dillah telah lama memeluk Islam secara diam-diam. Sehingga ibu tirinya yang dikenal sebagai Putri Champa diperlakukannya menurut cara yang sesuai dengan ajaran Islam. Lihat: Hamka. 1976. Sejarah Umat Islam Jilid IV. Jakarta. H. 147-148

${ }^{3}$ Pada masa Pangeran Sido Ing Kenayan bergelar Pangeran Ratu Sultan Jamaluddin Amangkurat IV di tahun 1633-1645 muncul tokoh Ratu Sinuhun yang merupakan Permaisuri yang sangat berpengaruh. Ratu Sinuhun dikenal sebagai salah satu penyusun Kitab Undang-Undang Hukum Adat "Simbur Cahaya" yang mengatur tata pergaulan dan adat istiadat masyarakat yang bersendikan syara' (Hukum Islam). Dan selanjutnya Penguasa-Penguasa Palembang diturunkan secara monarchi berdasarkan garis keturunan. Lihat: H. Rusydi Cosim. "Sejarah Kerajaan Palembang dan Perkembangan Hukum Islam, dalam K.H.O. Gadjahnata dan Sri-Edi Swasono (ed.). 1986. Masuk dan Berkembangnya Islam di Sumatera Selatan. Penerbit Universitas Indonesia Press. H. 207-209.
} 


\section{Kerangka Teoritik}

Kerangka teoritik digunakan peneliti agar dapat fokus dan mencapai tujuan yang telah ditetapkan. Kerangka teoritik berfungsi sebagai pedoman dalam mengeksplorasi seluruh rangkaian kegiatan dan data-data penelitian yang ditentukan peneliti secara subyektif. Teori merupakan hal yang mutlak dalam suatu penelitian. Semua penelitian dibangun atas sejumlah konstruksi teoritis, seberapapun implisitnya atau bahkan tanpa disadari oleh peneliti. ${ }^{4}$

Penelitian ini memfokuskan pada legislasi Peraturan Daerah yang mengandung ajaran Islam ini paling tidak memiliki 3 (tiga) variable utama yaitu: Analisis kebijakan, politik hukum dan politik perundangan-undangan di Indonesia, legislasi peraturan daerah, dan hukum Islam. Kerangka teoritik digunakan untuk lingkup kajian (3) tiga variable tersebut dan dilakukan pembatasan-pembatasan tertentu sehingga penelitian ini tidak terlalu luas, yang pada saat bersamaan secara realistis dapat dijangkau oleh peneliti. Guna merumuskan ruang lingkup dan kerangka teoritik secara tepat, maka akan dikemukakan beberapa teori yang sudah ada dan mapan dalam ilmu hukum. Hal ini dimaksudkan agar rumusan masalah dan ruang lingkup penelitian yang diketengahkan memiliki sandaran teoritik yang dapat dipertanggunjawabkan sisisisi ilmiahnya.

\subsection{Kebijakan Publik}

Analisa kebijakan yang terintegrasi dapat berfungsi sebagai sarana untuk menjembatani jurang pemisah antara pendekatan terhadap analisis kebijakan seperti perbedaan antara teori keputusan deskriptif dan normatif, inkrementalisme dan analisis sistem dan pendekatan empiris, valuatif dan normatif dalam analisis kebijakan. ${ }^{5}$ Selain itu, analisis kebijakan akan melebar melampaui produksi "fakta", karenanya para analis kebijakan akan berusaha untuk memproduksi sebuah infomasi dalam mengetahui serangkaian nilai-nilai dan tindakan-tindakan yang akan dipilih.

Kebijakan adalah suatu ucapan atau tulisan yang memberikan petunjuk umum tentang penetapan ruang lingkup yang memberi batas dan arah umum kepada seseorang untuk bergerak. Sedangkan kebijakan publik adalah segala sesuatu yang berkaitan dengan pekerjaan yang akan dikerjakan dan atau tidak dikerjakan oleh pemerintah. Kebijakan yang diambil oleh pemerintah sebagai pemegang kekuasaan harus mengedapankan kepentingan bersama berdasarkan pertimbangan kebutuhan masyarakat pada umumnya. Namun, kebijakan tersebut dapat dibatalkan apabila dikemudian ditemukan ketidaksesuaian atau sesuatu yang dapat merugikan khalayak banyak. Suatu kebijakan tidak selamanya menguntungkan satu pihak dan menguntungkan pihak lain. Artinya, kebijakan publik diambil berdasarkan pertimbangan kepentingan nasional secara

${ }^{4}$ Pelto, P.J., 1970, Anthropological Research: The Structure of Inquiry, New York, Harper and Row.H. 17. sebagaimana dikutip oleh Anna Marie Wattie, 2006, "Penelitian seksualitas, kedudukan teori dan pilihan paradigma" dalam Esei-Esei Antropologi, Teori, Metodologi dan Etnogtafi, Yogjakarta, Penerbit Kepel Press. H. 37.

${ }^{5}$ Kathleen A. Archibald, Three Views of the Expert's Role in Policy Making: Systems Analysis, Incrementalism, and the Clinical Approach, Polcy Sciences, 1, NO 1 (1970), hal 73-86 
komprehensif. Oleh karena itu, Rian Nugroho $^{6}$ mengemukakan bahwa pada dasarnya semua negara memiliki permasalahan dan isu yang relatif sama, perbedaannya adalah bagaimana pemerintah merespon masalah dan isu isu yang berkembang di masyarakat. Respon dari pemerintah terhadap isu dan permasalahan didalam istilah politik lebih dikenal dengan kebijakan.

Konsep kebijakan publik didalam istilah bahasa inggris sering kita dengar dengan istilah publicpolicy. Menurut Kamus Besar Bahasa Indonesia kebijakan diartikan sebagai rangkaian konsep dan asas yang menjadi garis besar dan dasar rencana dalam pelaksanaan suatu pekerjaan, kepemimpinan, dan cara bertindak (tentang pemerintahan, organisasi, dan sebagainya); pernyataan cita-cita, tujuan, prinsip dan garis pedoman untuk manajemen dalam usaha untuk mencapai sasaran. Atau dengan kata lain, kebijakan publik adalah suatu keputusan yang dimaksudkan untuk tujuan mengatasi permasalahan yang muncul dalam suatu kegiatan tertentu yang dilakukan oleh instansi pemerintah dalam rangka penyelenggaraan pemerintah. ${ }^{7}$

Dalam kepustakaan internasional kebijakan publik disebut sebagai public policy, yaitu suatu aturan yang mengatur kehidupan bersama yang harus dipatuhi dan ditaati serta berlaku mengikat bagi seluruh warganya. Setiap pelanggaran yang dilakukan oleh seseorang akan mendapatkan sanksi sesuai dengan bobot dan kebijakan yang telah ditetapkan oleh suatu badan yang memiliki otoritas untuk menjatuhkan dan atau menetapkan suatu hukuman. ${ }^{8}$ Untuk menjamin pelaksanaan kebijakan yang efisien dari kehendak negara, menurut Goodnow, maka fungsi administrasi pemerintah harus tunduk pada kontrol politik. ${ }^{9}$ Namun disisi lain lembaga tinggi negara seperti eksekutif, legislatif dan yudikatif harus tunduk pada peraturan perundang-perundangan yang berlaku. Sejauh para pemangku kebijakan patuh terhadap perundang-undangan yang berlaku, sejauh itulah masyarakat akan patuh pada hukum.

Awal mulanya, studi kebijakan publik didasarkan pada kontribusi dari empat tokoh utama yaitu: Harold D. Lasswell, Simon, Lindblom dan Easton. Lasswell (1970) adalah penstudi kebijakan publik utama yang berlaku sebagai bagian dari ilmu sosial. Simon (1945), adalah ahli yang berkontribusi dalam konteks pilihan rasional dalam pengambilan keputusan. Lindblom (1959) banyak menulis tentang Incrementalism secara ilmiah. Sedangkan Easton (1953) berkontribusi pada sistem politik dengan melalui model yang benar-benar

\footnotetext{
${ }^{6}$ Riant, Nugroho, 2014, Public Policy. Jakarta: PT. Elex Media Komputindo

${ }^{7}$ AR Mustopadidjaya, 2002, Manajemen Proses Kebijakan Publik, Formulasi, Implementasi dan Evaluasi Kerja, Jakarta LAN, hal 26

${ }^{8}$ Riant Nugroho Dwijowitoto, 2003, Kebijakan Publik: Formulasi, Implementasi dan Evaluasi, Jakarta: Elex Media Komputindo, hal. 1-7

${ }^{9}$ Frank Goodnow, 1990, Politics and Administration : A Study in Goverment, New York, the Macmillan Company: London, Macmillan \& co.ltd., hal 44
} 
mempengaruhi studi kebijakan publik serta hubungan antara proses input, output, dan kebijakan publik lingkungan. ${ }^{10}$

Dalam perkembangannya, kelahiran kebijakan publik sebagai sebuah disiplin ilmu tidak dapat dipisahkan dari peran seorang ilmuwan Harold D. Lasswell. Laswell yang merasakan perlunya sebuah disiplin ilmu baru yang fokusnya terhadap bagaimana hubungan pemerintah dan masyarakat sebagai warga negara setelah peristiwa perang dunia kedua periode 1940-1950. Kebijakan publik sebagai sebuah evolusi dari ilmu politik sangat penting dirasakan sebagai sebuah respon adanya perubahan dan penomena sosial yang semakin dinamis. Harold lasswell dalam bukunya "the policy orientation" menganggap ilmu sosial sebagai metode dalam pemecahan sosial dan dengan demikian dia mengambil kesimpulan diperlukannya sebuah ilmu tentang kebijakan sosial.

\subsection{Politik Hukum}

Menurut Mahfud MD., sumber hukum ada dua macam yaitu sumber hukum materiil dan sumber hukum formal. Sumber hukum materiil adalah bahanbahan hukum yang belum mempunyai bentuk tertentu dan belum mengikat secara formal namun dapat dijadikan isi hukum dengan bentuk tertentu agar menjadi mengikat, misalnya melalui proses legislasi. Sedangkan sumber hukum formal adalah sumber hukum yang telah mempunyai bentuk tertentu dan mengikat berlakunya sebagai hukum karena telah ditetapkan (diberlakukan) oleh lembaga yang berwenang seperti proses legislasi.

Selain melalui proses dan produk legislasi sumber hukum formal dapat juga berupa yurisprudensi, konvensi, dan doktrin. Yurisprudensi adalah putusan pengadilan yang telah mempunyai kekuatan hukum yang tetap dan diterima sebagai pedoman (diikuti) oleh hakim-hakim untuk dijadikan pedoman dalam menangani kasus yang sama. Konvensi adalah praktek ketatanegaraan dan pemerintahan yang berasal dari kebiasaan (tak tertulis) namun diterima sebagai kewajaran. ${ }^{11}$

Istilah politik hukum, secara etimologi berasal dari istilah hukum Belanda rechtspolitiek yang merupakan bentukan dari dua kata rech dan politiek, ${ }^{12}$ sedangkan dalam bahasa Arab kata hukum mengandung pengertian putusan, ketetapan, perintah, kekuasaan, hukuman dan lain-lain. Menurut Padmo Wahjono, Politik Hukum adalah kebijakan dasar yang menentukan arah, bentuk maupun isi dari dari hukum yang akan dibentuk. ${ }^{13}$ Sedangkan Sunaryati Hartono melihat politik hukum sebagai alat kontrol atau sarana dan langkah yang dapat diambil

10 Suratman Nur, Decentralization and Development in Public Policy Implementation Perspective; Case Study in Indonesia, IOSR Journal Of Humanities And Social Science (IOSRJHSS) Volume 17, Issue 6 (Nov. - Dec. 2013), hal. 27-33

${ }^{11}$ Mahfudz MD., Politik Hukum dalam Perda Berbasis Syari'ah, Jurnal Hukum No. 1 Vol. 14, Januari 2007, hal. 14

${ }^{12}$ Imam Syaukani dan A. Ahsin Thohari, Dasar-dasar Politik Hukum, PT RajaGrafindo Persada, Jakarta, 1999, hal. 19

\footnotetext{
${ }^{13}$ Padmo Wahyono, 1986, Indonesia Negara Berdasarkan atas hukum, Cet. II, Ghalia Indonesia,
} Jakarta., hlm. 160 
oleh pemerintahan untuk menciptakan suatu tatanan hukum nasional yang dikehendaki bersama dan dengannya cita-cita dan semangat menciptakan sistem hukum nasional dapat diwujudkan. ${ }^{14}$ Wilayah kerja politik hukum dapat meliputi pelaksanaan pelaksanaan ketentuan hukum yang ada secara konsisten, terjadinya proses pembuatan dan pembaruan hukum yang mengarah kepada sikap kritis terhadap hukum yang bersifat ius constituendum atau hukum yang dicita citakan dan diangan-angankan sesuai dengan kehendak dimasa depan, ${ }^{15}$ dengan menekankan pentingnya pembenahan pada aparat penegak hukum.

Politik hukum sebagai aktifitas memilih dan cara yang hendak dipakai untuk mencapai suatu tujuan sosial dan hukum tertentu dalam masyarakat. Garuda Nusantara memberikan definisi mengenai politik hukum atau dalam istilahnya disebut dengan legal policy, sebagai kebijakan umum yang hendak diterapkan atau dilaksanakan oleh pemerintah. Oleh karena itu, wilayah kerja politik hukum dapat meliputi pelaksanaan ketentuan hukum yang telah ada secara konsisten serta proses tersebut harus mengarah kepada sikap kritis terhadap hukum yang berdimensi ius contitutum dan menciptakan hukum yang berdimensi ius constituendum serta pentingnya penegasan fungsi lembaga dan pembinaan penegak hukum.

Situasi dan kebijakan politik yang sedang berlangsung sangat mempengaruhi sikap yang harus diambil oleh pemerintah, dan tentunya hal itu sangat berpengaruh pada produk-produk hukum yang dihasilkan, termasuk juga Peraturan daerah. Produk hukum responsif/otonom adalah produk hukum yang karakternya mencerminkan pemenuhan atas tuntutan-tuntutan baik individu maupun kelompok sosial di dalam masyarakat sehingga lebih mampu mencerminkan rasa keadilan di dalam masyarakat.

Proses pembuatan hukum responsif tidak langsung mengundang secara terbuka partisipasi dan aspirasi masyarakat, dan lembaga peradilan, hukum diberifungsi sebagai alat pelaksana bagi kehendak masyarakat. Produk hukum konservatif/ortodoks adalah produk hukum yang karakternya mencerminkan visi politik pemegang kekuasaan dominan sehingga pembuatannya tidak melibatkan partisipasi dan aspirasi masyarakat secara sungguh-sungguh. Biasanya bersifat formalitas dan produk hukum diberi fungsi dengan sifat positivis instrumentalis atau menjadi alat bagi pelaksanaan idiologi dan program pemerintah. ${ }^{16}$

\subsection{Relasi Agama dan Politik}

Dari 260 juta penduduk Indonesia, 85 persennya merupakan masyarakat yang menganut agama Islam. Dengan demikian, tidak dapat dipungkiri bahwa nuansa perundang-perundangan Indonesia, termasuk juga peraturab daerah banyak yang terinspirasi dari kitab suci umat Islam dan peradaban yang berkembang di masyarakat Islam, khususnya masyarakat Islam Indonesia.

\footnotetext{
${ }^{14}$ Sunaryati Hartono, 1991, Politik Hukum Menuju Satu Sistem Hukum Nasional, Alumni,Bandung, hlm: 1

${ }^{15}$ Mahfud MD, 2010, Membangun Politik, Menegakkan Konstitusi, Rajawali Pers, Jakarta, hlm: 15

${ }^{16}$ Mahfud MD, 2010, Membangun Politik, Menegakkan Konstitusi, Rajawali Pers, Jakarta, hlm: 6
} 
Ditengah kemajemukan tersebut, tokoh muslim Indonesia yang juga pendiri bangsa, seperti Sukarno, M. Yamin dan lain lain berusaha menawarkan kepada masyarakat Indonesia sebuah dasar negara yang mampu mengakomodir kepentingan masyarakat Indonesia yang majemuk. Sehingga tidak ada kesan bahwa negara Indonesia berdiri sebagai sebuah negara Islam, yang hanya menganut dan mengamalkan nilai-nilai dan ajaran Islam. Atas dasar pertimbangan kemajemukan tersebut, maka lahirlah pancasila sebagai sebuah dasar negara yang memiliki landasan historis politik yang kuat yang mampu mengakomodir kepentingan bangsa, sehingga seluruh lapisan masyarakat menerimanya sebagai sebuah negara yang syarat dengan kearifan dari para pendiri bangsa.

Pancasila sebagai sebuah dasar ideologi negara kehadirannya sangat tepat untuk menjawab kebutuhan negara kebangsaan Indonesia yang multi ras, multi kultur, multi etnis, multi agama, dan luas daerahnya. Namun, kurang bagusnya pelaksanaan nilai-nilai pancasila yang diamalkan oleh pemegang kebijakan/penguasa, maka pancasila yang sejatinya merupakan kesepakatan leluhur pendiri bangsa, maka pernah diplesetkan sebagai sebuah ideologi yang bukan-bukan. Sebenarnya menurut Fred W. Ringga Pancasila merupakan konsep prismatik yang menyerap unsur-unsur terbaik dari konsep-konsep yang beberapa elemen pokoknya saling bertentangan. Pancasila mengayomi semua unsur bangsa yang majemuk yang kemudian di dalam sistem hukum melahirkan kaidah-kaidah penuntun yang jelas.

Agama dan negara adalah dua entitas penting yang sama sama berfungsi bagi kehidupan manusia. Jika negara berada pada dimensi kekinian yang sekuler untuk memenuhi kebutuhan dunia, maka agama berperan pada dimensi religius yang tidak hanya untuk memenuhi kebutuhan yang sifatnya untuk kehidupan akhirat tetapi juga memikirkan persoalan-persoalan duniawi.

Secara historis-faktual, penerimaan ulama terhadap eksistensi Pancasila sebagai ideologi negara didasari oleh fakta bahwa warga negara Indonesia bersifat majemuk, sehingga persatuan dalam keragaman menjadi keniscayaan. Oleh sebab itu, menjadikan budaya lokal dan kearifan lokal secara proporsional dalam kehidupan Indonesia menjadi pilihan tepat. Penerimaan ulama tersebut terhadap Pancasila dalam wadah NKRI tidak lepas dari tahapan pemahaman trasendental, dimana para ulama pendiri negara tersebut telah mampu menangkap substansi norma agama setelah melalui pemahaman komprehensif dari berbagai sudut pandang, sehingga mampu menawarkan tata kehidupan berbangsa dan bernegara yang inklusif dan aspiratif. ${ }^{17}$

Menurut Hamka, bahwa ajaran Islam harus diwujudkan dalam kehidupan negara. Alat-alat negara harus melaksanakan nilai-nilai ajaran Islam. Meskipun Islam tidak mengatur persoalan negara secara detail tapi prinsip-prinsipnya ada dalam al-Qur'an dan al-Hadis. Persoalan bagaimana bentuk negara dan pemerintahan itu, maka hal ini menyangkut persoalan ijtihad. Dalam konstitusi

\footnotetext{
${ }^{17}$ M Amin Abdullah, Studi Agama: Normativitas dan Historisitas (Yogyakarta: Pustaka Pelajar,
} 1996), h. 11. 
negara boleh dicantumkan dan boleh juga tidak dicantumkan tentang negara Islam. Yang penting substansi ajaran Islam dilaksanakan. ${ }^{18}$

Idham Chalid berpendapat, ditentukannya tentang konsep Syura dan demokrasi terpimpin, menurutnya ada dua hal. Pertama, ketika dia menyatakan bahwa musyawarah (syura) adalah bukti adanya demokrasi dalam Islam atau dengan kata lain syura adalah demokrasi dalam Islam. Kedua, ketika Idham menyamakan beberapa hal dalam syura dengan demokrasi terpimpin. ${ }^{19}$

Menurut Adnan, hubungan agama dan negara dapat dibagi menjadi tiga kategori. Pertama, kelompok akomodatif. Kelompok ini dipelopori oleh Nurcholis Madjid. Nurcholis Madjid berpandangan bahwa kehidupan spiritual diatur oleh agama dan kehidupan duniawi di atur oleh logika duniawi. Pemikiran ini mengandung element "sekularistik", yaitu adanya upaya memisahkan antara agama dengan dunia, meskipun yang sebenarnya hanyalah pembedaan wilayah: ada wilayah yang semata-mata urusan agama dan ada wilayah yang semata-mata duniawi.

Akhirnya kekuasaan bukanlah tujuan, tetapi menjadi alat untuk melancarkan agama. Beliau datang membawa satu ideologi, yaitu Islam Kemudian dengan sendirinya terbentuk suatu kekuasaan di Madinah.Oleh karena itu, Hamka berpendapat bahwa dalam Islam tidak ada pemisahan antara urusan negara dari agama. Islam menghendaki hubungan yang harmonis dalam segala urusan yang berlaku di antara keduanya. ${ }^{20}$

\section{Hasil Penelitian}

Kota Palembang merupakan salah satu kota tua di Indonesia yang berdiri semenja tahun 682 M. Menurut data statistik tahun 1990, kota Palembang setidaknya 52,24 persen tanah di kota Palembang menurut topograpinya digenangi air. Leluhur palembang menamakan kota Palembang sebagai Pa-lembang dalam bahasa melayu $\mathrm{Pa}$ atau Pe sebagai kata tunjuk suatu tempat atau keadaan; sedangkan lembang atau lembeng artinya tanah yang rendah, lembah akar yang membengkak karena lama terendam air (menurut kamus melayu), sedangkan menurut bahasa melayu-Palembang, lembang atau lembeng adalah genangan air. Jadi Palembang adalah suatu tempat yang digenangi oleh air. ${ }^{21}$

Kota Palembang memiliki sejarah Sebagai Pusat Kerajaan Sriwijaya dan Kesultanan Palembang Darussalam. Kota Palembang mempunyai sejarah yang panjang. Bukti Kota Palembang sebagai pusat Kerajaan Sriwijaya dan Kasultanan Palembang didukung oleh adanya peninggalan-peninggalan bersejarah yang saat ini berfungsi sebagai aset budaya dan objek wisata seperti Prasasti Kedukan Bukit, TamanPurbakala Kerajaan Sriwijaya (TPKS), makam-makam raja-raja Palembang.

\footnotetext{
${ }^{18}$ Hamka, Islam: Revolusi Ideologi dan Keadilan Sosial, Jakarta: PT Pustaka Panjimas, hal. 91-93

${ }^{19}$ Ahmad Muhajir, Idham Chalid Guru Politik Orang NU, (Yogyakarta : LKiS, 2007), hal. 120.

${ }^{20}$ Ibid, hal. 86

${ }^{21}$ Sejarah Kota Palembang, diakses dari http://palembang.go.id/37/sejarah-kota-palembang pada tanggal 05 Oktober 2018
} 
Menurut data Badan Pusat Statistik Kota Palembang tahun 2016, jumlah penduduk kota Palembang sekitar 3.204.142 dan 3.170.352 penduduk kota Palembang menganut agama Islam. ${ }^{22}$ Menurut data statistik diatas, secara jelas dapat dikatakan bahwa hampir 95 persen penduduk kota Palembang menganut agama Islam sehingga mengakibatkan nuansa Islami di kota Palembang sangat kental dan syarat dengan nilai-nilai dan budaya Islam. Tidak heran jika semenjak zaman kesultanan Palembang hingga era reformasi pemerintah Palembang selalu memperhatikan aspirasi masyarakat salah satunya dengan membuat peraturan daerah yang benuansa Islam sehingga kepentingan vertikal warga Palembang dapat terakomodir dengan baik.

Pada zaman kesultanan Palembang, kitab hukum adat "Simbur Cahaya" dan Undang-undang wilayah, yaitu "Sindang Mardike" ${ }^{23}$ merupakan salah satu bukti bahwa pemerintahan Palembang pada saat itu sangat perhatian terhadap nilai-nilai, tradisi, adat dan kebudayaan Islam pada masa lalu. Sedangkan di bidang peradilan, dikenal dengan macam pengadilan yang mengadili dalam perkara-perkara keagamaan dipimpin oleh Pangeran Penghulu Nato Agamo, yang membawahi Pangeran-pangeran Penghulu.

Pusat kota Palembang secara historis awalnya terletak di tanah tinggi. Berdasarkan jejak arkeologis dari proklamasi Sriwijaya, yang terdapat dalam bait bait prasasti Kedukan Bukit, jantung kota Palembang berada di Bukit Seguntang. Secara harfiah Bukit Siguntang mengandung artian tanah yang membuntang, guntang atau terapung.Seiring dengan perjalanan waktu, terjadi pergeseran pusat kota Palembang,yang semula di Bukit Siguntang berpindah ke Kerat on Kuto Gawang. Perpindahan pusat kota tersebut tidak lain disebabkan oleh runtuhnya Kerajaan Sriwijaya dan berdirinya kesultanan Palembang.

Pada masa reformasi, setelah keluarnya Otonomi Daerah, Mahfud MD berpendapat bahwa meskipun Indnesia secara konstitusional bukanlah negara Islam melainkan negara pancasila, namun Indonesia memiliki landasan yang kuat dan kukuh bagi pengembangan korelasi dengan segala bentuk pengembangan pluralisme masyarakat Indonesia, yakni Pancasila sebagai dasar negara meletakkan negara dengan mayoritas penduduknya muslim, sebagai negara yang memiliki peluang untuk terselenggaranya syariat Islam ke dalam hukum Indonesia terutama ke dalam peraturan daerah yang di buat oleh DPRD bersama kepala daerah.

Lahirnya perda sangat bersinggungan dengan kepentingan daerah bersangkutan. Setidaknya terdapat 22 daerah yang mengimplemantasikan perda yang mengatur persoalan moralitas dan implementasi syariah Islam di semua lini kehidupan. Kehadiran Perda anti maksiat ataupun perda yang bernuansa pada Syariat Islam, di beberapa daerah Indonesia tidak saja menarik dicermati karena adanya pro dan kontra, tetapi juga pergulatan ide yang ada di balik perda-perda tersebut. Perda sebagai produk dari kebijakan publik tidak dapat dilepaskan dari

\footnotetext{
${ }^{22}$ https://palembangkota.bps.go.id/linkTableDinamis/view/id/19 diakses pada 02 Oktober 2018

${ }^{23}$ Boedani Djavid, Tambo Kerajaan Sriwidjaja, (Bandung: Terate, 1961),hlm. 26.
} 
sebuah proses politik yang melatarbelakangi lahirnya berbagai macam idealisasi politik yang dianut oleh para pembuat kebijakan.

Secara teoritis suatu Perda dibuat dikarenakan diproyeksikan mampu menyelesaikan masalah-masalah publik yang sangat strategis. Masalah dalam konteks kebijakan publik berarti adanya kondisi dan situasi yang secara formal menghasilkan kebutuhan-kebutuhan atau ketidakpuasan-ketidakpuasan dalam masyarakat sehingga perlu dicari cara-cara penanggulangannya. Persoalan Perda di kota Palembang tidak dapat dilepaskan dari adanya tuntutan dan kebutuhan masyarakat Palembang akan adanya tuntunan syariat Islam yang diresmikan atau di formalkan dalam sebuah hukum yang berlaku dan mengikat untuk masyarakat kota Palembang.

Adanya partisipasi masyarakat secara langsung dalam sebuah rancangan peraturan perundang-undnagan telah dijamin dalam undang undang. Jaminan partisipasi masyarakat diatur dalam undang undang No 12 tahun 2011 tentukan pembentukan peraturan perundang-undangan di Indonesia. Masyarakat berhak memberikan masukan baik secara lisan maupun tertulis dalam pembentukan peraturan perundang-undangan yang dapat dilakukan melalui rapat dengan pendapat umum, kunjungan kerja, sosialisasi dan atau seminar/lokakarya/diskusi.

Dalam pandangan Islam, persoalan syariah bukanlah persoalan yang sederhana yang sekedar jika ditetapkan akan lebih baik dan jika tidak ditetapkan tidak berdosa (sunnah). Dalam syariah Islam, semua pemeluk agama Islam wajib tunduk dan patuh terhadap syariah Islam. Kepatuhan kepada hukum Allah adalah bukti keimanan seseorang kepada Allah SWT. Perbedan mendasar antara hukum positif dan hukum Islam adalah hukum positif merupakan pernyataan kehendak manusia yang terhimpun dalam wadah yang biasa disebut dengan negara. Selain itu, hukum positif adalah sebuah instrumen yang dibuat dan ditetapkan oleh politik. Pembentukan hukum mencerminkan konfigurasi kekuatan dan kepentingan politik sedangkan hukum Islam merupkan hukum yang ketetapannya ada pada Allah yang maha kuasa.

Perspektif sosiologis mengungkapkan bahwa nilai, norma, adat, kebiasaan, kesepakatan sosial dan sebagainya yang ada dalam setiap elemen masyarakat sebagai hukum rakyat tidak berlaku universal. Sementara hukum negara bersifat universal, memaksa, dan seragam. Maka dalam konteks ini, penerapan syariat Islam melalui peraturan daerah sangat efektif dikarenakan memiliki dampak sosiologis, psikologis dan dampak hukum pada masyarakat yang mengikat di kota tersesebut.

Mengenai Perda yang berkaitan langsung dengan moralitas masyarakat seperti pemberantasan atau pelarangan praktik prostitusi di kotanya, dengan pertimbangan utama pemerintah daerah melarang prostitusi adalah untuk mempertahankan nilai luhur masyarakat agar tidak bertentangan dengan norma agama dan kesusilaan. Kegiatan prostitusi dikategorikan sebagai kejahatan sehingga layak diganjar dengan hukuman kurungan penjara seperti yang tertera dalam Perda Palembag adalah selaama 6 bulan atau denda sekurang-kurangnya lima juta rupiah. Sehingga, baik agama Islam maupun agama lainnya dipastikan tidak akan merasa keberakatan dengan pemberlakuan peraturan tersebut. 
Berkaitan dengan prostitusi, pemerintah Kota Palembang pada tahun 2004 telah mengeluarkan peraturan daerah yang melarang kegiatan prostitusi di wilayah hukum kota Palembang. Maksud dari lahirnya Perda ini adalah agar pelacuran yang mempengaruhi tata kehidupan bermasyarakat dan sebagai upaya untuk merubah sikap mental yang mempengaruhi sendi-sendi kehidupan masyarakat kota Palembang. ${ }^{24}$

Kurungan atau denda materi menjadi cara mengerem kegiatan prostitusi. Dalam Convention for the Supression of the Traffic to Person and of the Prostituion of Others tahun 1949, Konvensi Penghapusan Diskriminasi terhadap Perempuan (diratifikasi Pemerintah RI dengan Undang-Undang Nomor 7 Tahun 1984), perdagangan perempuan dan prostitusi dimasukkan sebagai bentuk kekerasan terhadap perempuan. Berdasarkan konvensi tersebut, dapat dikatakan prostitusi bukanlah jalan hidup yang dipilih, tetapi suatu keterdesakan situasi. Hal inilah yang harusnya mendorong para pembuat kebijakan lebih peka melihat persoalan. Biasanya, munculnya praktik prostitusi dilatar belakangi oleh faktor ekonomi. Kelemahan pemerintah Indonesia saat ini yang yang paling menonjol adanya ketidak mampuan mengatasi dan mengentas kemiskinan sehingga mengakibatkan masyarakat cenderung berfikir pendek dan mengambil langkah yang merugikan diri sendiri dan masyarakat.

Meskipun Perda prostitusi tidak mengatasi secara keseluruhan prostitusi di Kota Palembang, paling tidak telah mengurangi dan telah menertibkan PSK sehingga tidak menularkan penyakit lebih jauh lagi, terutama kepada para remaja dan di tempat-tempat terbuka. Namun, jika seandainya kegiatan prostitusi tersebut tidak ditertibkan, dapat berakibat pada keberanian untuk lebih menyasar pasar yang lebih jauh seperti para pelajar dan ditempat tempat ruang terbuka. Karena selain persoalan ekonomi, persoal prostitusi biasanya tetap ada dikarenakan masyarakat yang gemar menghibur diri melalui jasa jasa prostitusi.

Seperti yang dijelaskan dalam Perda diatas yakni pada pasal 7 dan 8 disebutkan bahwa pelacuran adalah perbuatan yang dilakukan seseorang dan atau sekelompok orang dengan sadar, bertujuan mencari kepuasaan syahwat diluar ikatan pernikahan yang sah dengan maksud mencari uang atau bentuk lainnya maka dapat dilakukan tindakan hukum apabila dilakukan ditempat-tempat seperti; jalan umum, lorong, gang, lapangan terbuka, penginapan hotel dan tempat tempat umum lainnya.

Dengan lahirnya perda ini tentunya, meskipun tidak dapat menghentikan, paling tidak dapat mengurangi dan atau membatasi kegiatan prostitusi dikota Palembang karena Palembang dari zaman kesultanan hingga sekarang dikenal dengan warga kotanya yang bersikap islami dan taat dalam menjalankan nilainilai dan ajaran agama Islam.

Peraturan daerah yang lainnya yang bermuatan syariah Islam adalah tentang pelarangan pengedaran dan penjualan minuman beralkohol pada tahun 2006 yang ditetapkan pada masa walikota Eddy Santana Putra. Al-qur'an menyebut miras pada surat al-Baqarah ayat 219 sebagai sebuah dosa besar meskipun terdapat manfaat didalamnya, namun dampak bahayanya lebih besa

\footnotetext{
${ }^{24}$ Perda Kota Palembang Nomor 2 Tahun 2004 tentang Pemberantasan Pelacuran
} 
ketimbang manfaatnya. Mengenai Perda miras, DPD RI pernah mengusulkan agar diberlakukan disemua daerah. DPD RI menyebut bahwa Minuman keras (miras) secara faktual telah menyebabkan banyak dampak buruk di berbagai daerah. ${ }^{25}$ Dari mulai tindakan kriminal, konflik sosial, hingga jatuhnya korban jiwa. Kemunculan berbagai macam perda miras yang membatasi hingga melarang, merupakan bentuk reaksi atas kegelisahan terkait masalah tersebut,"

Aksi-aksi kejahatan yang diakibatkan oleh pengaruh minuman beralkohol disebabkan karena sifat dari minuman beralkohol yang apabila dikonsumsi secara berlebihan akan menyebabkan tidak sadar diri dengan berbagai efek tubuh seperti muntah-muntah, tertidur, mabuk dengan melakukan berbagai gangguan yang merugikan kehidupan masyarakat, seperti gangguan terhadap lalu lintas dengan berbagai akibatnya, kriminalitas, dan sebagainya. Sehingga, secara kriminologis, pecandu alkohol (alkoholisme) merupakan faktor kriminogen atau penyebab utama timbulnya kejahatan. $^{26}$

Sebagai upaya untuk mengantisipasi kemungkinan terjadinya hal-hal yang tidak diinginkan terkait langsung dengan keberadaan minuman beralkohol, selain kota Palembang, pemerintah pusat juga sudah membuat aturan guna mengawasi dan mengendalikan peredarannya, seperti: Keputusan Presiden Nomor 3 Tahun 1997 tentang Pengawasan dan pengendalian Minuman Beralkohol, Peraturan Menteri Perdagangan Nomor 45/M-DAG/PER/12/2010, Jo Peraturan Menteri Perdagangan Nomor 20/M-DAG/PER/7/2011, Jo Peraturan Menteri Perdagangan Nomor 11/M-

DAG/PER/3/2012, JoPeraturan Menteri Perdagangan Nomor 53/MDAG/PER/12/2012 tentang Ketentuan Pengadaan, Pengedaran, Penjualan, Pengawasan, dan Pengendalian Minuman Beralkohol dan Peraturan Menteri Perdagangan Republik Indonesia Nomor: 15/M-DAG/PER/3/2006 tentang engawasan dan Pengendalian Impor, Pengedaran dan Penjualan, dan Perizinan Minuman Beralkohol.

Peraturan Daerah lainnya yang dikeluarkan oleh pemerintah kota Palembang berkaitan dengan kehidupan umat Muslim Kota Palembang adalah mengenai pengelolaan zakat yang ditetapkan pada masa walikota Harnojoyo pada tahun 2017 yang lalu. Pemerintah daerah kota Palembang yang menerbitkan Peraturan tentang Pengelolaan Zakat memiliki visi, misi, dan tujuan yang sama dengan undang-undang pengelolaan zakat yaitu meningkatkan kesejahteraan para mustahik. Hal ini sejalan dengan tujuan pembangunan di negara Indonesia yaitu membangun masyarakat adil dan makmur.

Peraturan Daerah tentang pengelolaan zakat yang dikeluarkan oleh Pemerintah Provinsi, Kabupaten/Kota di Indonesia merupakan peraturan normatif bagi pengelolaan zakat infak sedekah di wilayahnya serta mengacu pada UndangUndang RI Undang-Undang Republik Indonesia Nomor 23 Tahun 2011 Tentang

\footnotetext{
${ }^{25}$ https://www.liputan6.com/news/read/2513653/dpd-ri-dorong-perda-miras-diberlakukan-disemua-daerah diakses pada 3 Oktober 2018

${ }^{26}$ Soedjono Dirdjosisworo, Alkoholisme: Paparan Hukum dan Kriminologi, Penerbit Remadja Karya, Bandung, 1984, hlm. 145
} 
Pengelolaan Zakat bagian ketiga pasal 15 dinyatakan bahwa Dalam rangka pelaksanaan pengelolaan zakat pada tingkat provinsi dan kabupaten/kota dibentuk BAZNAS provinsi dan BAZNAS kabupaten/kota.

Dalam membuat Perda, Pemerintah Daerah harus memperhatikan pasal 7 ayat 1 undang undang Nomor 10 tahun 2004 tentang pembentukan peraturan perundang-undangan dimana Perda harus mempertimbangkan substansi UndangUndang Dasar Republik Indonesia tahun 1945, Peraturan Pemerintah Pengganti Undang-undang, Peraturan Pemerintah, dan peraturan presiden sebagai acuan dalam merumuskan peraturan daerah.

Ditinjau dari perspektif moral, khususnya kalangan pelajar dan remaja, lahrinya dua peraturan daerah tersebut merupakan sebuah tuntutan publik agar karakterikstik dan moralitas remaja di kota Palembang senantiasa mengedepankan sifat yang mulia. Selain itu, tidak ada satu agamapun yang menghalalkan pelacuran dimuka bumi. Maka dilihat dari perspektif sosiologis, keberadaan peraturan daerah tentang pelacuran merupakan inisiatif publim yang dilakukan form buttom to up dan dilegalkan dalam bentuk peraturan daerah.

Masyarakat kota Palembang yang kental dengan pemahaman keagamaannya, tentunya sangat bersuka cita dengan lahirnya peraturan daerah yang mengakomodir kepentingan mereka, selain itu, tiga perda syariah yang ada di Palembang, sebetulnya lebi merupakan peraturan turunan dari pemerintah pusat. Sehingga, disamping berusaha sejalan dengan aturan pemerintah pusat, masyarakat muslim Palembang juga terkesan tidak ego-sentris terhadap pemahaman keagamaannya.

Keinginan masyarakat kota Palembang yang sangat terhadap hadirnya kota Palembang yang jauh dari perbuatan maksiat dalam hal ini prostitusi, akan terasa efektif apabila dibentuk dan dituangkan dalam sebuah aturan yang jelas. Maka, kehadiran perda anti prostitusi dan miras merupakan jawaban yang tepat dari keinginan masyarakat setempat. Karena sejatinya faktor yang paling dominan mempengaruhi efektifitas suatu perundang-undangan adalah profesional dan optimal pelaksanaan peran serta wewenang dan fungsi dari aparat penegak hukum, baik didalam menjalankan tugas yang dibebankan terhadap diri mereka maupun dalam penegakkan perundang-undangan tersebut.

\section{Kesimpulan}

Lahirnya perda sangat bersinggungan dengan kepentingan daerah bersangkutan. Setidaknya terdapat 22 daerah yang mengimplemantasikan perda yang mengatur persoalan moralitas dan implementasi syariah Islam di semua lini kehidupan.Sepanjang penelitian ini, meskipun ada beberapa penelitian yang menyebutkan bahkan terjadinya pelanggaran HAM ketika menerapkan Peraturan Daerah, khususnya yang berkaitan dengan ubudiyah, namun sejatinya Perda yang ditetapkan oleh Pemerintah dan Legislatif kota Palembang sangat toleran dan kebijakan tersebut hanya dalam rangka menjaga moralitas perilaku masyarakat kota Palembang.

Sejalan dengan kearifan lokal dalam konteks hukum, pendekatan budaya (cultur approach) sesuai dengan aliran hukum sociological jurisprudence bahwa hukum yang baik adalah hukum yang sesuai dengan tatanankehidupan 
masyarakat. Maksudnya pendekatan budaya dengan melibatkan kearifan lokal dan lembaga adat merupakan langkah yang strategis dan efektif karena dalam masyarakat telah mempunyai sistem hukum yang hidup yang dikenal dengan hukum adat sebagai bagian dari tradisi kultur masyarakat Indonesia.

Oleh sebab itu, penyelesaian masalah-masalah moralitas dengan mengedepan keterlibatan masyarakat serta dengan menggunakan adat lokal atau kearifan lokal dinilai sangat tepat karena memadukan budaya dan tradisi hukum dalam masyarakat.

Kearifan lokal dalam merumuskan dan menyusun Perda syari'ah di kota Palembang lebih kentara ketimbang munculnya isu-isu ego umat muslim di Palembang yang menurut Azyumardi Azra sebuah kearifan lokl dapat dijadikan mekanisme sosio kultural yang terdapat dalam tradisi masyarakat Indonesia.

Efektifitas implementasi kebijakan dalam kasus penelitian ini adalah tiga Perda Syari'ah di kota Palembang, membutuhkan keterlibatan stakeholders(dalam hal ini Walikota, DPRD Kota Palembang, tokoh agama dan tokoh masyarakat) secara demokratis dan partisipatif. Stakeholders dan pembuat kebijakan harus terus menerus terlibat dalam dialog untuk menganalisis konsekuensi dari pelaksanaan kebijakan tersebut.

Berbagai masalah dan fenomena sosial yang terjadi disekitar masyarakat dapat didekati dan diselesaikan dengan kebijakan yang tepat. Sebuah kebijakan sekalipun tidak populis, namun mampu menyelesaikan permasalahan kemasyarakatan dapat dikatakan berhasil. Oleh karena itu, kebijakan harus diambil dan dianalisas sedemikian rupa, sehingga tepat pada sasaran dan kebutuhan publik.

\section{Daftar Pustaka}

A. Syaukani, dkk. 2003. Otonomi Daerah dalam Negara Kesatuan. Jakarta. Pustaka Pelajar.

Abdul Latif dan Hasbi Ali. 2011, Politik Hukum. Jakarta: PT Prestasi Pustakarya. Abu al-Hasan al-Mawardi,tanpa tahun, al-Ahkaam al-Shulthaaniyyah Beirut Dar al-Fikri.

Agustino,Leo, 2008, Dasar-Dasar Kebijakan Publik, Penerbit Alfabeta, Bandung Ahmad Muliadi. 2013. Politik Hukum. Padang. Akademia Permata.

Aini, Nurul. 2005. "Dewan Perwakilan Rakyat Daerah dan Demokratisasi Pemerintahan Daerah" Dalam Haris, Syamsuddin (Edt) Desentralisasi dan Otonomi Daerah, Desentralisasi, Demokratisasi \& Akuntabilitas Pemerintah Daerah Jakarta LIPI Press

Alfian. 1992. "Pancasila Sebagai Ideologi Dalam Kehidupan Politik". Dalam Oetojo Oesman dan Alfian (Ed.)

Ali, Zainudin, 2007, Sosiologi Hukum,Jakarta, Sinar Grafika.

Alexander, Harry 2004 Panduan Perancangan Peraturan Daerah di Indonesia Jakarta XSYS Solusindo 
Kiki Mikail, Yazwardi | Tamaddun: Jurnal Kebudayaan dan Sastra Islam, Vol. XVIII No. 2, 2018 |

Alfian 1992 "Pancasila sebagai Ideologidalam Kehidupan Politik" Dalam Oetojo Oesman dan Alfian Pancasila Sebagai Ideologi dalam Berbagai Bidang Kehidupan Bermasyarakat, Berbangsa dan Bernegara Jakarta BP-7 Pusat

Amiroeddin Syarif. 1997.Perundang-undangan: Dasar, Jenis dan Teknik Membuatnya, Cetakan ke-2, Rineka Cipta, Jakarta

Anna Marie Wattie. 2006, "Penelitian seksualitas, kedudukan teori dan pilihan paradigma" dalam Esei-Esei Antropologi, Teori, Metodologi dan Etnografi, Yogjakarta, Penerbit Kepel Press.

Arfawie Kurde. 2005. Telaah Kritis Teori Negara Hukum, Konstitusi dan Demokrasi Dalam Kerangka Pelaksanaan Desentralisasi dan Otonomi Daerah Berdasarkan UUD-1945. Pustaka Pelajar, Yogyakarta.

Arskal Salim and Azyumardi Azra (ed.). 2003. Shariá and Politics in Modern Indonesia, Singapore: ISEAS.

Arskal Salim. 2008. Challenging the Secular State, the Islamization of Law in Indonesian modern. Honolulu. University of Hawai'i Press.

Artidjo Alkostar. 1997. Menelusuri Akar dan Merancang Hukum Nasional dalam Artidjo Alkostar (ed.), Identitas Hukum Nasional, Fakultas Hukum UII, Yogyakarta.

Asshiddiqie,Jimly, 2006, Teori Hans Kelsen Tentang Hukum, Jakarta: Penerbit Sekretariat Jenderal \& Kepaniteraan Mahkamah Konstitusi RI

Attamimi, A Hamid S. 1981. UUD 1945, TAP MPR, Undang-Undang (Kaitan Norma Hukum Ketiganya) Jakarta, 31 Desember 1981

Azyumardi Azra. 1999. Jaringan Ulama: Timur Tengah dan Kepulauan Nusantara Abad XVII dan XVIII. Bandung: Mizan.

--------, 2002. Islam Nusantara: Jaringan Global dan Lokal. Bandung: Mizan -2002, Reposisi Hubungan Agama dan Negara: Merajut Kerukunan Antar umat, Jakarta: Kompas

---------, 2004, Jaringan Ulama Timur Tengah Dan Kepulauan Nusantara Abad XVII \& XVIII, Bandung: Mizan

---------, 2005. "Syariah Islam dalam Bingkai Nation State", dalam Komaruddin Hidayat dan Ahmad Gaus (ed.), Islam Negara \& Civil Society Gerakan dan Pemikiran Islam Kontemporer. Jakarta: Paramadina.

Bagir Manan. 1992. Dasar-dasar Perundang-undangan di Indonesia. Jakarta. Ind-Hill Co,

---------, 1994. Hubungan antara Pusat dan Daerah Menurut UUD 1945. Pustaka Sinar Harapan, Jakarta

, 1995. Empat Tulisan Tentang Hukum.Bandung: Program Pascasarjana BKU Hukum Ketatanegaraan. Universitas Padjajaran

Bahtiar Effendy. 1998. Islam dan Negara; Transformasi Pemikiran dan Praktik Politik Islam di Indonesia, Jakarta Paramadina

Bakir, Herman. 2005. Kastil Teori Hukum Jakarta. PT INDEKS.

--------,. 1990. Politik Islam di Indonesia. Jakarta: Ghalia Indonesia 1990. Hukum Dan Politik di Indonesia, Kesinambungan dan Perubahan, Cet I, LP3S, Jakarta 
Dirdjosisworo,Soedjono, 1984, Alkoholisme: Paparan Hukum dan Kriminologi, Penerbit Remadja Karya, Bandung

Djavid, Boedani ,1961, Tambo Kerajaan Sriwidjaja, Bandung: Terate

Dwijowitoto, Riant Nugroho, 2003, Kebijakan Publik: Formulasi, Implementasi dan Evaluasi, Jakarta: Elex Media Komputindo

Dwiyanto, Agus. (et al). 2002. Reformasi Tata Pemerintahan dan Otonomi Daerah, Ringkasan Eksekutif Pusat Studi Hukum dan Kebijakan Universitas Gadjah Mada, Yogyakarta

Elizabeth A. Martin and Jonathan Law. 2006. A Dictionary of Law. Sixth Edition. Oxford University Press, New York,.

Fachry Ali dan Bahtiar Effendy. 1986. Merambah Jalan Baru Islam: Rekonstruksi Pemikiran Islam Indonesia Masa Orde Baru. Bandung: Mizan.

Ferejohn, John. 2005. Participation and Democracy. Stanford University

Fery Edward . 2002. "Teknik Penyusunan Peraturan Perundang-undangan Tingkat Daerah". Makalah Pendidikan dan Latihan Legal Drafting LAN, Jakarta.

Goodnow,Frank, 1990, Politics and Administration : A Study in Goverment, New York, the Macmillan Company: London, Macmillan \& co.ltd

Hans Kelsen. 1995 Teori Hukum Murni: Dosar-dasar Ilmu Hukum NormatifDeskrlptif, Rimdi Press, Jakarta.

Haris, Syamsuddin. 2002. "Konflik Elite Sipil dan Dilema Konsolidasi Demokrasi Pasca Orde Baru" Dalam Maruto MD \& Anwari WMK (Ed). Reformasi Politik dan Kekuatan Masyarakat, Kendala dan Peluang Menuju Demokrasi. Pustaka LP3ES, Jakarta

Hartono, Sunaryati, 1991, Politik Hukum Menuju Sistem Hukum Nasional, Alumni, Bandung

Harun Nasution. 1989. Islam Ditinjau dari berbagai Aspeknya. Jilid II. Jakarta: UI Press.

, 1995. " Pengantar" dalam Harun Nasution dan Bahtiar Effendy (Penyunting). Hak Azasi Manusia dalam Islam. Jakarta: Yayasan Obor Indonesia dan Pustaka Firdaus

Hasbi Ash Shiddieqy. 1985. HukumIslam. Jakarta. Penerbit Bulan Bintang.

Hassibuan. 1993. Ilmu Negara Jakarta. Ghalia Indonesia.

Huntington, Samuel P dan Nelson, Joan No Easy Choice Political Participation in Developing Countries Diterjemahkan oleh Simamora, Sahat. 1994. Partisipasi Politik di Negara Berkembang. Rineka Cipta, Jakarta

Imam Syaukani dan A Ahsin Thohari. 2004. Dasar-dasar Politik Hukum. PT Raja Grafindo Persada, Jakarta

Jeremy Bentham. 1996. An Introduction to the Principles of Morals and Legislation. J.H. Burns and H.L.A. Hart (ed.). Clarendon Press, Oxford;

Jimly Asshiddiqie.1994. Gagasan Kedaulatan Rakyat dalam Konstitusi dan Pelaksanaannya di Indonesia, Jakarta: Ichtiar Baru van Hoeve. -, 2004. Konstitusi dan Konstitusionalisme Indonesia, Cetakan-I, MKRI dan Pusat Studi HTN FH-UI, Jakarta.

, 2006. Pengantar llmu Hukum Tata Negara Jilid I, Cetakan ke-1, Konstitusi Press, Jakarta

John Rawls. 1973. A Theory of Justice. Oxford University Press, London 
Kiki Mikail, Yazwardi | Tamaddun: Jurnal Kebudayaan dan Sastra Islam, Vol. XVIII No. 2, 2018 |

Johny Ibrahim. 2006. Teori dan Metodologi Penelitian hukum Normatif. Malang. Banyu Media Publishing.

Mahfud MD, Moh. 1993. Demokrasi dan Konstitusi di Indonesia. Liberty, Yogyakarta

---------, 1998. Politik Hukum di Indonesia. Pustaka LP3ES Indonesia, Jakarta

--------, 1999. Hukum dan Pilar-Pilar Demokrasi. Gama Media, Yogyakarta

---------, 1999. Pergulatan Politik dan Hukum di Indonesia. Gama Media, Yogyakarta

---------, 2003. Demokrasi dan Konstitusi di Indonesia, Studi tentang Interaksi Politik dan Kehidupan Ketatanegaraan .Rineka Cipta, Jakarta

---------, 2006. Membangun Politik Hukum, Menegakkan Konstitusi LP3ES, Jakarta

Muhajir,Ahmad, 2007, Idham Chalid Guru Politik Orang NU, Yogyakarta : LKiS

Muhammad Iqbal. 2007. Fiqh Siyasah Kontekstualisasi Doktrin Politik Islam. Jakarta: Gaya Media Pratama.

Nawawi,Ismail, 2009, Public Policy: Analisis, Startegi Advokasi teori dan praktek. Surabaya: Putra Media Nusantara.

R Smith,Thomas, 1983, The Policy Implementation Process, Elservier Scientific Publishing Company, Amsterdam, Printed In Scotland

Abdul wahab,Solichin, 2008, Analisis Kebijaksanaan: dari Formulasi

Salman, Otje dan Susanto, Anton F. 2004. Teori Hukum, Mengingat, Mengumpulkan dan Membuka Kembali. Refika Aditama, Bandung

Santos, Bonaventura de Sousa. 1995. Toward a New Common Sense: Law, Science and Politics in Paradidgmatic Transition. Routledge, New York

Seidman, Robert B. Tanpa tahun. Law and Development: A General Model. University of Wiscounsin, Madison

Siswanti Sunarno. 2014. Hukum Pemerintahan Daerah di Indonesia. Jakarta. Sinar Grafika.

Sunarno. 2014. Hukum Pemerintahan Daerah di Indonesia. Jakarta. Sinar Grafika.

Sunaryati Hartono, 1991. Politik Hukum Menuju Satu Sistem Hukum Nasional, Alumni, Bandung

Sunyoto Usman. 2004. "Otonomi Daerah, Desentralisasi dan Demokratisasi". Dalam Edy Suardi Hamid dan Sobirin Malian (Ed.) Memperkokoh Otonomi Daerah, Kebijakan, Evaluasi dan Saran. UII Press, Yogyakarta.

Syarif Hidayat. 2002. Refleksi Realitas Otonomi Daerah dan Tantangan ke Depan. Pustaka Quantum, Jakarta.

Shidarta. 2006. Karakteristik Penalaran Hukum dalam Konteks Keindonesiaan. CV. Utomo, Bandung

Sirajuddin dkk.2006. Leglslatif Drafting Pelembagaan Metode Partisipatif dalam Pembentukan Peratutran Perundang-undangan, Cetakan keI,APPIKA, Malang.

Sirajuddin et.al. 2006. Legislative Drafting, Pelembagaan Metode Partisipatif dalam Pembentukan Peraturan Perundang-undangan. Malang Corruption Watch dan YAPPIKA, Jakarta, 
Tamaddun: Jurnal Kebudayaan dan Sastra Islam, Vol. XVIII No. 2, 2018|171

Sunarno, Siswanto, 2009, Hukum Pemerintahan Daerah Di Indonesia,Jakarta Sinar Grafika.

Sunaryati Hartono. 1991. Politik Hukum Menuju Satu Sistem hukum Nasional, Alumni, Bandung, 1991

Syaukani, Imam dan A. Ahsin Thohari, 1999, Dasar-dasar Politik Hukum, PT RajaGrafindo Persada, Jakarta,

Wahyono,Padmo, 1986, Indonesia Negara Berdasarkan atas hukum, Cet. II, Ghalia Indonesia, Jakarta

Yusril Ihza Mahendra. 1996. Dinamika Tata Negara Indonesia. Jakarta: UI-Press

---------, 1998. "Menelaah Format Politik Orde Baru" Dalam Dahlan Thaib dan Mila Karmila Adi (Ed.) Hukum dan Kekuasaan Fakultas Hukum Universitas Islam Indonesia. Yogyakarta

---------,. 2002. Mewujudkan Supremasi hukum di Indonesia (catatan dan gagasan). Sekretariat jenderal Departemen Kehakiman dan Hak Asasi Manusia Republik Indonesia. Jakarta 